\title{
Ethnopharmacology of Souroubea sympetala and Souroubea gilgii (Marcgraviaceae) and identification of betulinic acid as an anxiolytic principle
}

\author{
Eva Puniani ${ }^{\mathrm{a}}$, Christian Cayer ${ }^{\mathrm{b}, \mathrm{c}}$, Pamela Kent ${ }^{\mathrm{b}, \mathrm{c}}$, Martha Mullally ${ }^{\mathrm{d}}$, Pablo Sánchez-Vindas ${ }^{\mathrm{e}}$, \\ Luis Poveda Álvarez ${ }^{\mathrm{e}}$, Victor Cal ${ }^{\mathrm{f}}$, Zul Merali $^{\mathrm{b}, \mathrm{c}}$, John T. Arnason ${ }^{\mathrm{d}, *}$, Tony Durst ${ }^{\mathrm{a}}$ \\ a Department of Chemistry, University of Ottawa, Ottawa, ON K1N 6N5, Canada \\ ${ }^{\mathrm{b}}$ University of Ottawa Institute of Mental Health Research, School of Psychology and Department of Cellular Medicine, Ottawa, ON K1N 6N5, Canada \\ ${ }^{\mathrm{C}}$ University of Ottawa Institute of Mental Health Research, School of Psychology and Department of Psychiatry, Ottawa, ON K1N 6N5, Canada \\ ${ }^{\mathrm{d}}$ Department of Biology, University of Ottawa, Ottawa, ON K1N 6N5, Canada \\ e JVR Herbaium Universidad Nacional, Heredia 3000, Costa Rica \\ ${ }_{\mathrm{f}}^{\mathrm{f}}$ Belize Indigenous Training Institute, Punta Gorda, Belize
}

\section{A R T I C L E I N F O}

Article history:

Available online $\mathrm{xxxx}$

This contribution is in honor of Professor Vince de Luca's 60th birthday.

\section{Keywords:}

Souroubea gilgii and S. sympetala

Marcgraviaceae

Anxiety

Betulinic acid

Elevated plus maze

Anxiolysis

\begin{abstract}
A B S T R A C T
The neotropical lianas Souroubea gilgii and Souroubea sympetala (Marcgraviaceae) were chosen for study as part of a phytochemical discovery strategy focusing on rare plant families in Central America. In participatory research, Q'eqchi' healers in Belize reported the use of these plants to reverse psychological symptoms inflicted by witchcraft. Extracts of two Souroubea species showed significant anti-anxiety activity in the elevated plus maze, a standardized test paradigm. Bioassay guided isolation led to the active principle, the pentacyclic triterpene, betulinic acid, which had activity in the elevated plus maze at $0.5 \mathrm{mg} / \mathrm{kg}$. Other phytochemicals isolated included $\alpha$ - and $\beta$-amyrin, 2-hydroxyursolic acid, taraxenyl trans-4-hydroxy-cinnamate, naringenin, methyl ursolate, eriodytiol, methyl 2- $\alpha$-hydroxyursolate, methyl 2- $\alpha$-hydroxymaslinate, methyl betulinate, and condrilla sterol.
\end{abstract}

(c) 2014 Published by Elsevier Ltd.

\section{Introduction}

The Marcgraviaceae is a small family of approximately 125 species of neotropical lianas, sometimes epiphytic, native to the northern part of South America, Central America and the Caribbean Islands (Gentry, 1993). The Marcgraviaceae was targeted for study as part of a biodiversity discovery strategy focusing on rare and less well studied plant families. For the present study, two closely related Central American species were collected for investigation: Souroubea gilgii Gilg. and Souroubea sympetala V.A. Richt..

South American species of Souroubea are mentioned in "The Healing Forest" (Schultes and Raffauf, 1990) who reported use of Souroubea guianensis Aublet var coralline (Mart) Wittmack by the Kubuyari in the Amazon. Dry leaves were boiled to prepare a calming drink for nervous elders. S. guianensis Aublet var cylindrica Wittmack is used as a tranquilizing medicine by the Karijona and as a treatment for "susto" by the Taiwanos. Susto is a culture

\footnotetext{
* Corresponding author. Tel.: +1 613562 5262; fax: +1 6135625765 .

E-mail address: John.Arnason@uOttawa.ca (J.T. Arnason).
}

bound syndrome describing medical conditions which are believed to result from a fright. Previous ethnopharmacological work has shown that other medicinal plants used for treatment of susto have GABAergic activity in vitro and anxiolytic properties in animal models (Awad et al., 2009; Bourbonnais-Spear et al., 2007).

These published South American ethnobotanical investigations suggested that the genus Souroubea may contain ingredients with psychopharmacological activity. In an initial investigation of the Central American species S. sympetala, promising anxiolytic activity in rats was detected using an extract prepared by supercritical $\mathrm{CO}_{2}$ methods, which is suitable for use as a natural health product (Mullally et al., 2011). The present study, provides details of the biological activity, ethnobotany, evidence for an active principle and other phytochemicals present in the plants. The first objective of the study was to provide further dose response data for a conventional alcohol extract in behavioral assays and to relate this pharmacological activity to traditional ethnobotanical use in Central America. An ethnobotany study was carried out in collaboration with Q'eqchi' Maya healers in Belize who have a rich ethnobotanical tradition using rainforest species (Amiguet et al., 2005) 
and who provided information on traditional knowledge of safety, preparation and dose information. The second objective was to confirm the identity of the active principles using a bioassay guided isolation approach. The last objective was to identify other major characteristic secondary metabolites of $S$. sympetala and $S$. glgii using standard phytochemical isolation methods.

\section{Results and discussion}

Anxiolytic effect of ethanol extracts of S. sympetala in a dose response study

To assess the activity of the ethanolic extracts administered to rats in a paradigm designed to measure anxiety like behavior, the elevated plus-maze (EPM) test was used (Fig. 1A). Ethologically,
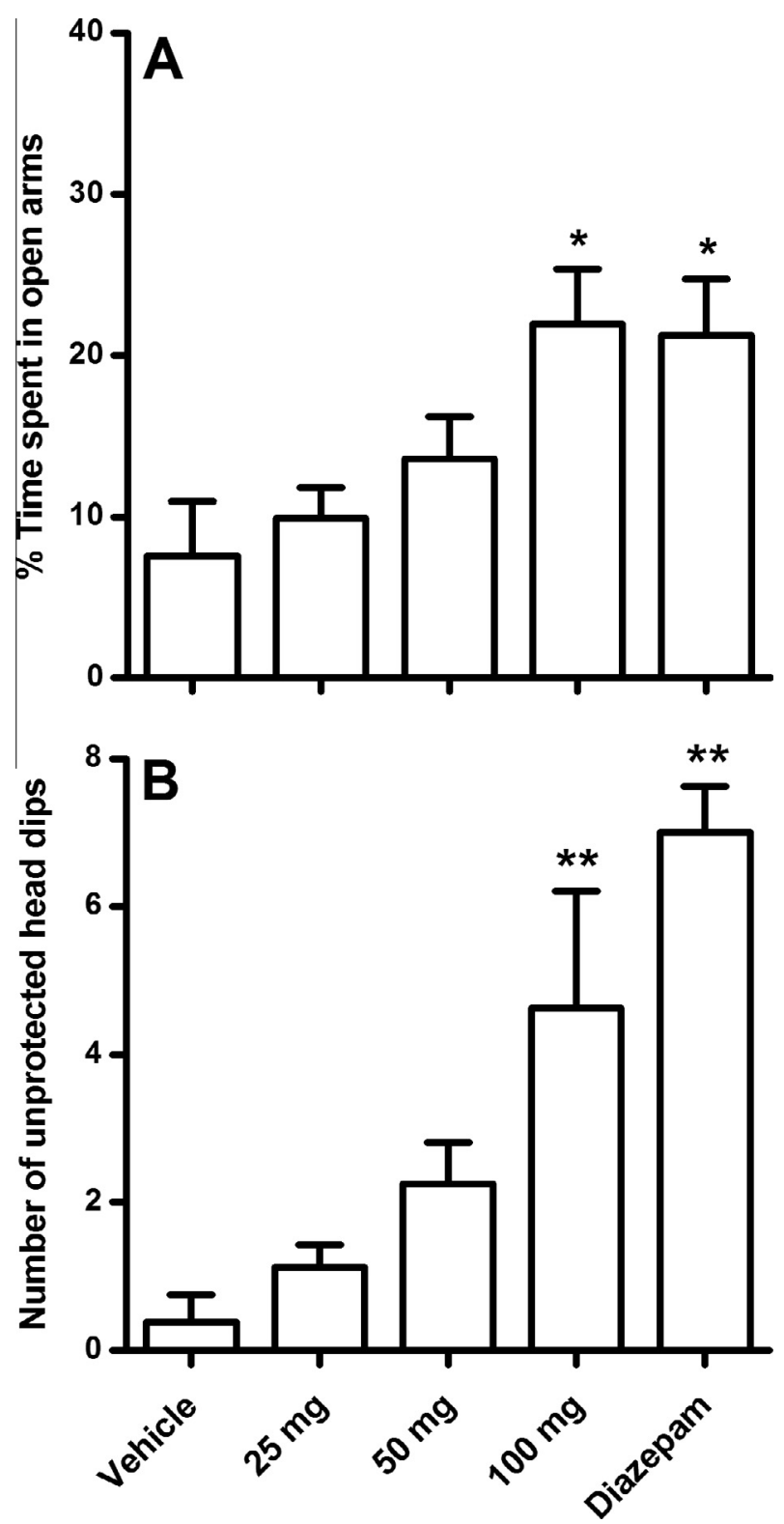

Fig. 1. Effects of diazepam ( $2 \mathrm{mg} / \mathrm{kg}$ ) and dose response in $\mathrm{mg} / \mathrm{kg}$ of the crude ethanolic extract of leaves of $S$. sympetala on the percentage of time spent on the open arms (A) and the number of unprotected head dips (B) in the elevated plus maze by orally administered rats $(n=8$ for vehicle, $n=8$ for all crude ethanolic extract doses, $n=12$ for diazepam). ${ }^{*} p<0.005,{ }^{* *} p<0.001$ indicate significant differences from vehicle. the contextual contrast between the open arms and the closed arm areas is meant to measure in each individual rat their natural propensity for exploratory behavior. Because of the increased risk of predatory challenge, the open arm area is considered an aversive stimulus, and also because of the natural fear of rats to open spaces. The positive control diazepam, a well known anxiolytic, significantly increased time spent on the open arm and the number of unprotected head dips (Fig. 1B). When the crude extract of $S$. sympetala was administered at three different doses to groups of animals, there was a dose dependent increase in time spent on the open arms of the maze and unprotected head dips (Fig. 1B). At a dose of $100 \mathrm{mg} / \mathrm{kg}$ the time spent in the open arm (22\%) was significantly different from controls (7\%), a threefold change. The number of unprotected head dips in the $100 \mathrm{mg} / \mathrm{kg}$ group (5) was also significantly different from controls (0.5), representing a tenfold change. Changes in these behavioral parameters are larger than previously observed with other known anxiolytic plant extracts such as skullcap (Awad et al., 2003). Similar results were obtained with several collections of S. sympetala and S. gilgii made at different times or with different collection sites (data not shown).

\section{Ethnobotany}

In participatory research with nine healers from the Q'eqchi' Maya traditional healer's association, at Indian Creek, Belize, the healers were shown a pressed herbarium specimen from Costa Rica of S. sympetala without prior discussion of our animal studies or review of Amazonian ethnobotany. Four of the nine healers recognized the plant immediately and indicated that they treated patients with it. The healers showed us several locations where the plant grows near streams. Vouchers collected during this field work were later taxonomically verified as authentic S. sympetala. $S$. gilgii was later collected near Punta Gorda Belize by the healers, who were unable to distinguish it from the more common S. sympetala. The healers use the leaves and bark to make a tea for the treatment of witchcraft, fever, ulcer, and dysentery. In patients putatively affected by witchcraft, the symptoms recognized by the healers include weight loss, becoming withdrawn, showing little interest in daily life and reduced verbal communication. According to the healers, treatment with a decoction prepared from $S$. sympetala improves the patient's mood and restores normal behavior. The dose specified was $20-30 \mathrm{~g}$ of leaf stem/liter of water, boiled for several minutes. The patient is instructed to drink 1 cup, twice a day, for 3 days. When asked about adverse effects, the healers indicated there were none. These results demonstrate similar use for $S$. sympetala among indigenous people in Central America as for S. guianensis in the Amazon (Schultes and Raffauf, 1990).

Bioassay guided isolation of active principle and other phytochemical markers

The above elevated plus maize test was repeated with the ethyl acetate soluble (f1) and more polar fractions (f2-f4) of S. sympetala and demonstrated that the anxiolytic activity resided in the f1 fraction (Fig. 2).

Subsequent chromatography of 11 on silica gel allowed to us to identify a number of triterpenes and flavonoids (Fig. 3), and to identify betulinic acid, $\mathbf{1}$, as the major anti-anxiety principle in the extract. Its concentration in the crude extract was determined to be $6.78 \pm 0.18 \mathrm{mg} / \mathrm{g}$ extract via HPLC and administration of pure betulinic acid 1 at $0.5 \mathrm{mg} / \mathrm{kg}$ increased the time spent in the open arms of the elevated plus maze significantly (Fig. 4). No further improvement was observed when the dosage was increased to $2.5 \mathrm{mg} / \mathrm{kg}$. Several but not all other components isolated from the ethyl acetate soluble portion of the extract (Fig. 4) were also 


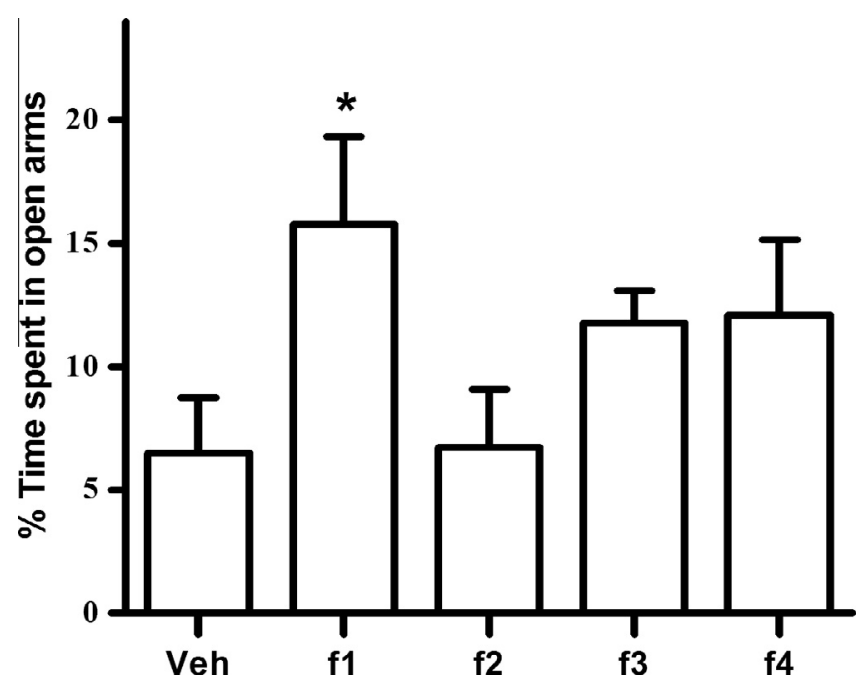

Fig. 2. Effects of the four different fractions ( $f 1, f 2, f 3, f 4$, ) on the percentage of time spent in the open arms in rats in the elevated plus maze following 3 consecutive daily oral administration of $100 \mathrm{mg} / \mathrm{kg}$ of their respective treatments ( $n=9$ for vehicle, $n=7$ for $\mathrm{f} 1, n=7$ for $\mathrm{f} 2, n=9$ for $\mathrm{f} 3, n=9$ for $\mathrm{f} 4$ ). ${ }^{*} p<0.05$ indicates a significant difference from vehicle.

tested, because of the time and expense in carrying out in vivo tests. The $\alpha$ - and $\beta$-amyrins, $\mathbf{5}$ and $\mathbf{6}$, were not very active at these concentrations. Oleanolic acid, $\mathbf{3}$, which is closely related to betulinic acid $\mathbf{1}$ was tested and shown to be inactive. Ursolic acid, shown as the methyl ester, $\mathbf{9}$ was also inactive (data not shown).

The yield of betulinic acid $\mathbf{1}$ after chromatography and recrystallization was $36 \mathrm{mg}$ or $150 \mu \mathrm{g} / \mathrm{g}$, dry weight. These yields are comparable to approximately a dozen other species which are now known to contain this important compound (Yogeeswari and Sriram, 2005).

Although the related compound betulin has reported neurological activity (Muceniece et al., 2008), this is the first report of the anxiolytic activity of betulinic acid, 1. Betulinic acid, 1, specifically, and related triterpenes, have been known for more than 60 years. They have recently received considerable interest with the discovery that derivatives of betulinic acid, $\mathbf{1}$ have considerable potential in the treatment of cancer and HIV (Yogeeswari and Sriram, 2005). For example, the derivative 4, derived from betulinic acid and 2,2-dimethyl succinic anhydride has been shown to have potent anti-HIV activity and was advanced to Phase II clinical trials as a component of an anti-HIV drug cocktail. It is truly remarkable that betulinic acid 1, first isolated in 1937, could become the basis of treatment in three widely different medical indications: antiviral, anti-cancer and anti-anxiety, and that this activity was discovered in a relatively short period of time. It is highly likely that other triterpenoid acids, beyond betulinic acid, 1, ursolic acid and oleanoic acid or their derivatives will also show valuable biological activity.

\section{Other phytochemical constituents of the leaves and fruit of S. sympetala}

In a subsequent experiment, leaves of $S$. sympetala collected at Las Horquetas from the same three vines used initially, were extracted as before to yield $29.7 \mathrm{~g}$ of ethanol soluble material and $99 \mathrm{~g}$ of insoluble fiber. Extraction of the ethanol soluble material with ethyl acetate afforded $5.4 \mathrm{~g}$ of a dark green gummy solid. This material was subjected to silica gel column chromatography and separated into five major fractions.

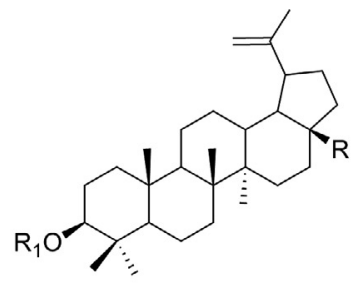

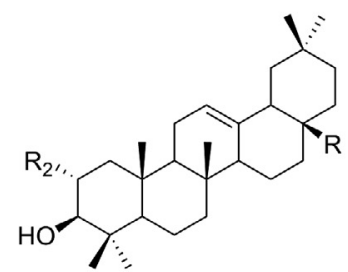<smiles>[R]C12CC[C@@H](C)[C@H](C)[C@H]1C1=CC[C@@H]3[C@](C)(CC[C@@H]4C(C)(C)[C@@H](O)CC[C@@]43C)[C@H]1CC2</smiles>

1, $\mathrm{R}=\mathrm{CO}_{2} \mathrm{H}, \mathrm{R}_{1}=\mathrm{H}$

2, $\mathrm{R}=\mathrm{CO}_{2} \mathrm{CH}_{3}, \mathrm{R}_{1}=\mathrm{H}$

4, $\mathrm{R}=\mathrm{CO}_{2} \mathrm{H} ; \mathrm{R}_{1}=\mathrm{COCH}_{2} \mathrm{C}\left(\mathrm{CH}_{3}\right)_{2} \mathrm{CO}_{2} \mathrm{H}$
3, $\mathrm{R}=\mathrm{CO}_{2} \mathrm{H}$

$6, \mathrm{R}=\mathrm{CH}_{3}$

12, $\mathrm{R}=\mathrm{CO}_{2} \mathrm{CH}_{3}, \mathrm{R}_{2}=\mathrm{OH}$
5, $\mathrm{R}=\mathrm{CH}_{3}$

9, $\mathrm{R}=\mathrm{CO}_{2} \mathrm{H}_{3}, \mathrm{R}_{2}-\mathrm{H}$

$11 \mathrm{R}=\mathrm{CO}_{2} \mathrm{CH}_{3}, \mathrm{R}_{2}=\mathrm{OH}$

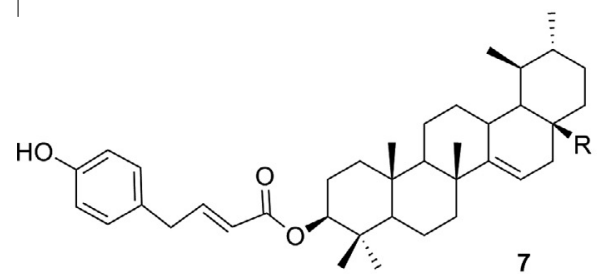<smiles>CC[C@H](/C=C/[C@@H](C)[C@H]1CCC2C3=CC[C@@H]4C[C@@H](O)CC[C@]4(C)C3CC[C@]21C)C(C)C</smiles>

13<smiles>O=C1CC(c2ccc(O)cc2)Oc2cc(O)cc(O)c21</smiles><smiles>O=C1CC(c2ccc(O)c(O)c2)Oc2cc(O)cc(O)c21</smiles>

Fig. 3. Phytochemicals isolated from ethyl acetate soluble fraction (f2) of S. sympetala leaves. 


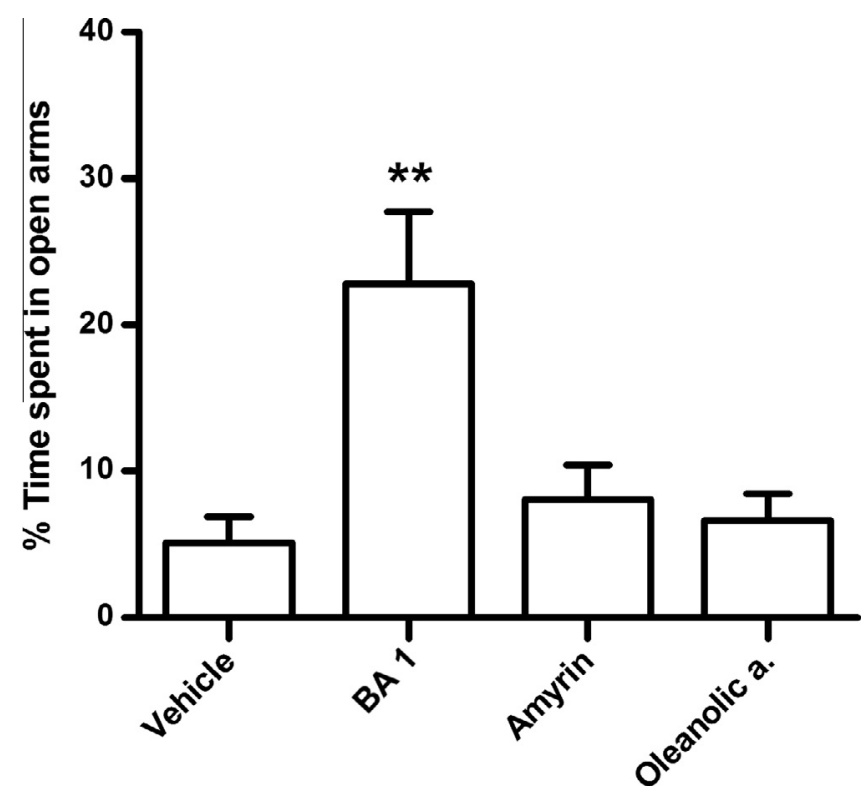

Fig. 4. Effects of several structurally related compounds: betulinic acid $\mathbf{1}(0.5 \mathrm{mg} / \mathrm{kg})$, $\alpha$ - and $\beta$-amyrins $(0.5 \mathrm{mg} / \mathrm{kg})$ and oleanolic acid $(0.5 \mathrm{mg} / \mathrm{kg})$ on the percentage of time spent on the open arms in the elevated plus maze by orally administered rats ( $n=10$ for all groups). ${ }^{* *} p<0.01$ indicates a significant difference from vehicle.

Fraction 1 (710 $\mathrm{mg})$, the least polar fraction, appeared according to its ${ }^{1} \mathrm{H}$ NMR spectrum to consist mainly of glyceride esters of a variety of fatty acids. This fraction was not investigated further.

Fraction 2 (800 mg) was subjected to chromatography to yield, after recrystallization from ethanol, an inseparable mixture of $\alpha$ and $\beta$-amyrins, 5 and 6, respectively (Mahato and Kundu, 1994; Seo et al., 1975). A subfraction (100 mg) was further purified via chromatography to afford $62 \mathrm{mg}$ of a white solid that was identified by comparison of its spectroscopic properties as taraxenyl trans-4-hydroxy-cinnamate, 7 (Kokpol et al., 1990; Talapatra et al., 1981). Saponification afforded taraxol, (Sakurai et al., 1986) and 4-hydroxycinnamic acid.

Fraction 4 (900 mg) was first treated with diazomethane to aid in the isolation process. Chromatography of the resultant material yielded, in order of increasing polarity: (i) linoleic acid methyl ester, (180 mg); (ii) two methylated derivatives of naringinin, 8, (4,7dimethyl ether (Lam and Wrang, 1975; Rossi et al., 1997; Duddeck et al.,1978), (10 mg); and the 7 methyl ether, (60 mg) (Vasconcelos et al., 1998; Agarwal et al., 1984) and (iii) methyl ursolate, 9, (24 mg) (Vasques da Silva et al., 2002; Doddrell et al., 1974).

Fraction 5 was also first reacted with diazomethane and then subjected to chromatographic purification, from which was isolated compounds identified as the partly methylated flavone eriodictyol, 10 (22 mg) (Miyazawa et al., 2000;Rauter et al., 1989), methyl 2- $\alpha$-hydroxyursolate, 11 and methyl 2 - $\alpha$-hydroxymaslinate, 12, and methyl betulinate, 2 (Seo et al., 1981; Das and Shashi, 1982; Kojima and Ogura, 1986), respectively. The smaller yield of betulinic acid $\mathbf{1}$ obtained in the second extraction may be partly due to efforts to focus on the other constituents and differences in the weather, especially the timing of the rainy season. Other extractions were carried out on leaves that were dried at about $50{ }^{\circ} \mathrm{C}$ shortly after harvest. These yielded similar results to those described above. Most of the major phytochemical markers also appear in S. gilgii, and we are currently looking for minor but unique markers that may distinguish the two species.

An extraction of the fruits of $S$. sympetala yielded $21.2 \mathrm{~g}$ dried insoluble pulp and $8.6 \mathrm{~g}$. of ethanol soluble extract. The yield of ethyl acetate soluble material was $370 \mathrm{mg}$. From this material was isolated $20 \mathrm{mg}$ of betulinic acid $\mathbf{1}$ and $22 \mathrm{mg}$ of condrilla sterol 13 (Junkuszew et al., 1998; Sucrow et al., 1976; Iyer and Iyer, 1978). The isolated yield of betulinic acid 1 based on dried fruit was $0.06 \%$.

Only the triterpenes betulinic acid, 1 ursolic acid and oleanolic acid have been previously reported from Souroubea spp. (Mullally et al., 2011) and all of the other compounds are new reports for the genus. However, 11 of the compounds isolated from the leaves and the fruit of $S$. sympetala and S. gilgii have previously been isolated from a variety of other plant sources. The structures of the compounds were assigned by comparison of the $\mathrm{mp}$ and available literature spectroscopic data with those obtained. In each case, the HRMS of the sample also helped secure the MF of the compounds identified.

\section{Concluding remarks}

The remarkable concordance of ethnological use between Q'eqchi' Maya healers and Amazonian indigenous groups is surprising because there is no communication between these widely separated groups. The results suggest that healers in separate locations have been adept at recognizing and putting to use the highly significant psychopharmacological effects of the plant. Although these effects are described in traditional concepts, the present study clearly shows that anxiolytic effects are an experimentally validated activity that corresponds to traditional use. Betulinic acid 1 is the major active principle, but the high level of activity of crude extracts suggests that the related triterpenes and/or flavonoids may have an additive or synergistic effect. The material is a superior plant derived anxiolytic among a large number of plant materials tested recently and may represent a promising replacement for Kava.

\section{Experimental}

\section{Plant material}

S. sympetala Gilg. leaves, stem and fruit were collected by two of us (Poveda Alvarez and Sanchez-Vindas) at Las Horquetas de Sarapiqui Costa Rica. S. gilgii Al Richter, was collected at the edge of canals near Toruguero, Costa Rica. Both species were also collected from Indian Creek, Toledo District Belize. The plant material was immediately covered with EtOH $-\mathrm{H}_{2} \mathrm{O}(95: 5, \mathrm{v} / \mathrm{v})$ ethanol for storage until phytochemical workup. Voucher specimens were deposited in the JVR herbarium, Universidad Nacional and the University of Ottawa Herbarium (OTT No. 19,915 and 19,916).

\section{Extracts for bioassay}

Plant parts were macerated with EtOH- $\mathrm{H}_{2} \mathrm{O}(95: 5, \mathrm{v} / \mathrm{v})(10 \mathrm{~mL} /$ $\mathrm{g}$ ) in a food blender, the mixture filtered under suction and the solids washed with additional EtOH $(5 \mathrm{~mL} / \mathrm{g})$. The combined extracts were then evaporated, via rotary evaporation and lyophilized to dryness to yield the sin susto crude extract (CE). The CE was partitioned between the $\mathrm{EtOH}_{2}$ soluble fraction (f1) and $\mathrm{H}_{2} \mathrm{O}$-soluble fraction (f2) to provide polar and non-polar fractions. Also further fractionation of the residue from (f2) was undertaken. It was extracted with EtOH- $\mathrm{H}_{2} \mathrm{O}(95: 5, \mathrm{v} / \mathrm{v})(10 \mathrm{~mL} / \mathrm{g})$ by stirring and heating the whole until reflux began, this being maintained, for $5 \mathrm{~min}$ before filtration of solids and concentration of liquid under reduced pressure. The resulting soluble substance was labeled as fraction 3 (f3) and the remaining insoluble fraction was labeled fraction 4 (f4). 
Animals

The behavioral experiments were conducted with male Sprague-Dawley rats (225-250 g body mass; Charles River Laboratories Inc., St. Constant, Quebec). Rats $(n=50)$ were housed individually and maintained under standard animal room conditions (clear plexiglass cages, $24 \times 30 \times 18 \mathrm{~cm}, 12 \mathrm{~h}$ light-dark cycle, $21 \pm 1{ }^{\circ} \mathrm{C}, 60 \%$ humidity, Purina Lab Chow and tap water ad libitum). All experimental procedures were approved by the Research Ethics Committee of the University of Ottawa and met the guidelines set out by the Canadian Council on Animal Care (CCAC). All attempts were made to minimize the number of animals used in the study, while maintaining the qualityof the experiments and results.

\section{Drug administration}

The plant extracts and fractions were suspended in sweetened, condensed milk- $\mathrm{H}_{2} \mathrm{O}(50: 50 \%, \mathrm{v} / \mathrm{v}) 1-4$ days prior to testing and stored at $4{ }^{\circ} \mathrm{C}$. To do this, the extract was frozen at $-80^{\circ} \mathrm{C}$, pulverized in an ice-cold mortar and pestle, and mixed with sweetened, condensed milk- $\mathrm{H}_{2} \mathrm{O}$ to a final concentration of $75 \mathrm{mg} / \mathrm{kg}$. Vehicle and plant extract treated rats were orally administered the respective treatments daily for three days (between 10:00-14:00 for two days prior to testing, $60 \mathrm{~min}$ prior to testing). Each dosage day, rats were orally administered either sweetened condensed milk-water vehicle $(2 \mathrm{~mL} / \mathrm{kg})$, plant extract $(25,50$ or $100 \mathrm{mg} / \mathrm{kg}$ ) or diazepam ( $2 \mathrm{mg} / \mathrm{kg}$ ). Following later isolation of pure compounds, these were administered and tested in a similar protocol but at lower doses.

\section{Behavioural assays}

The elevated plus maze is a validated test used to assess anxiety-like behaviour in laboratory rodents. It consists of two open arms $(50 \times 10 \mathrm{~cm})$, two perpendicular arms enclosed by $40 \mathrm{~cm}$ high walls, and is placed $50 \mathrm{~cm}$ above the ground. The design is based on the conflict between the animal's instinct to explore its environment and its fear of exposed areas and heights. Black curtains surrounded the chamber to limit the influence of spatial cues and other extraneous stimuli. A video camera was mounted above the arena to permit remote monitoring and recording. Rats $(n=7-$ 12 /group) were individually placed in the testing room for $1 \mathrm{~h}$ acclimatization. Each rat was then placed onto the open central platform of the EPM (facing a closed arm). The rats behaviour was monitored for $5 \mathrm{~min}$ and scored as follows: (1) frequency of entries onto the open arms, (2) percentage of time spent on the open arms (time open $/ 300 \times 100$ ), (3) frequency of entries in the closed arms, and (4) unprotected head dips (UH); head protruding over the edge of an open arm and down toward the floor, which is an index of risk assessment behavior. Between tests, the elevated plus maze was cleaned with isopropanol-water $(70: 30 \%, v / v)$. The percent of time in the open arms, frequency of open arm entries, and unprotected head dips are all validated measures of anxietylike behaviour in the EPM. Increases in these measures are indicative of reduced anxiety, whereas decreases compared to vehicles suggest increased anxiety. In contrast, the frequency of closed arm entries is an index of general activity.

\section{Ethnobotany}

Participatory research with nine healers from the Q'eqchi' Maya traditional healer's association, was undertaken at Indian Creek, Belize with whom we have a 10 -year relationship. A research agreement is in place with the association and its parent organization, the Belize Indigenous Training Institute. The research protocol was approved by the University of Ottawa ethics committee.
Isolation of the anti-anxiety principle in S. sympetala and identification of other phytochemicals present

The crude EtOH extracts ( $40.1 \mathrm{~g}$ ), and a residue of dry fiber $(178 \mathrm{~g})$ were obtained by treating the leaves as described above. The CExtract was further extracted twice by stirring overnight with EtOAc $(200 \mathrm{~mL})$. The EtOAc soluble fractions were combined and evaporated to yield a gummy solid $(8.0 \mathrm{~g})$. The latter was subjected to silica gel G column chromatagraphy (CC) (70-200 mesh) and eluted with hexane with stepwise increments of $\mathrm{EtOH}_{2}$, to produce 5 fractions. In some cases, these were subjected to additional chromatography yielding pure compounds that were identified by comparison of their ${ }^{1} \mathrm{H}$ and ${ }^{13} \mathrm{C}$ NMR spectra taken in $\mathrm{CDCl}_{3}$ on a Bruker AMX-500 instrument, with literature values, reported in the references below. New HRMS characterization was via HRMS using a Kratos VG 7070E spectrometer.

Betulinic acid, 1. (Fujioka et al., 1994); HRMS. Cacd. for $\mathrm{C}_{30} \mathrm{H}_{48} \mathrm{O}_{3}$ : 456.3604. Found: 456.3590.

$\alpha$ and $\beta$-Amyrins, 5 and 6. (Mahato and Kundu, 1994; Seo et al., 1975). HRMS. Cacd for $\mathrm{C}_{30} \mathrm{H}_{50} \mathrm{O}: 426.3862$. Found: 426.3840.

Taraxenyl trans-4-hydroxy-cinnamate, 7. (Kokpol et al., 1990; Talapatra et al., 1981). HRMS: Cacd for $\mathrm{C}_{39} \mathrm{H}_{56} \mathrm{O}_{3}: 572.4223$. Found: 572.4242 .

Naringinin, 8, (4',7-dimethyl ether (Lam and Wrang, 1975; Rossi et al., 1997; Duddeck et al.,1978). HRMS: Cacd for $\mathrm{C}_{17} \mathrm{H}_{16} \mathrm{O}_{5}$ : 300.0998. Found: 300.0990 .

Methyl ursolate, 9, (Vasques da Silva et al., 2002; Doddrell et al., 1974). HRMS. Cacd for $\mathrm{C}_{31} \mathrm{H}_{50} \mathrm{O}_{3}$ : 470.3760. Found: 470.3751 .

Eriodictyol, 4',7-dimethyl ether, 10, (Miyazawa et al., 2000; Rauter et al., 1989). HRMS. Cacd for $\mathrm{C}_{17} \mathrm{H}_{16} \mathrm{O}_{6} .31609347$. Found: 316.0946.

Methyl 2- $\alpha$-hydroxyursolate, 11 and methyl 2- $\alpha$-hydroxymaslinate, 12. (Mahato and Kundu, 1994). Cacd for $\mathrm{C}_{31} \mathrm{H}_{50} \mathrm{O}_{4}$ : 486.3709. Found: 486.3696

Methyl betulinate, 2 (Seo et al., 1981; Das and Shashi, 1982; Kojima and Ogura, 1986). HRMS. Cacd for $\mathrm{C}_{31} \mathrm{H}_{50} \mathrm{O}_{3} .470 .3759$. Found: 470.3766 .

Condrilla sterol 13 (Junkuszew et al., 1998; Sucrow et al., 1976; Iyer and Iyer, 1978). HRMS. Cacd for $\mathrm{C}_{29} \mathrm{H}_{48} \mathrm{O}: 412.3705$. Found: 412.3690 .

\section{HPLC analysis}

Analyses were performed with an Agilent 1100 HPLC MSD VL APCI system consisting of an autosampler, quaternary pump, photodiode array detector (DAD) and online APCI-MS with a mass range of 50-15,000 Da (Agilent, Palo Alto, CA, USA). A Waters YMC, ODS-AM column $(100 \times 2 \mathrm{~mm}$ I.D.; $3 \mu \mathrm{m}$ particle size, $120 \AA$ ), maintained at $45^{\circ} \mathrm{C}$ was used at a flow rate of $0.4 \mathrm{~mL} /$ min. Elution conditions were optimized with a mobile phase of $\mathrm{H}_{2} \mathrm{O}$ (solvent A) and $\mathrm{CH}_{3} \mathrm{CN}$ (solvent B) as follows: initial conditions: $70 \% \mathrm{~A}: 30 \% \mathrm{~B}$, linear gradient to $100 \% \mathrm{~B}$ in $10 \mathrm{~min}$, maintained at 100\% B for 8 min and returned to $70 \% \mathrm{~A}: 30 \% \mathrm{~B}$ in $7 \mathrm{~min}$, post-time $3 \mathrm{~min}$, for a total run time of $28 \mathrm{~min}$. An aliquot $(1 \mu \mathrm{L})$ of each extract was injected through the autosampler for each run and the elution profiles monitored via MS.

Detection and quantification of triterpenoids was conducted via MS. The mass spectrometer was tuned in positive ion mode at the beginning of all experiments. The optimized spray chamber conditions were: drying gas flow rate of $5.0 \mathrm{~L} / \mathrm{min}$; nebulizer pressure of 
$60 \mathrm{psi}$; drying gas temperature of $200^{\circ} \mathrm{C}$; vaporizer temperature of $325^{\circ} \mathrm{C}$; capillary voltage of $3200 \mathrm{~V}$; and corona current of $5.0 \mu \mathrm{A}$. The MS was operated in scanning ion mode (SIM) and tuned to detect ions with a mass/charge $(\mathrm{m} / \mathrm{z})$ ratio of 439.1 (BA), 439.2 (UA) and $409.2(\alpha-A$ and $\beta-A)$ which correspond to the molecular mass of each marker triterpenoid following the loss of a hydroxyl group and hydrogen atom during fragmentation.

\section{Acknowledgments}

The authors acknowledge gratefully the support to JTA and TD in the form of NSERC Discovery and I2I grants which allowed us to initiate and carry forward this work. We also recognize the contributions of John Baker, Bioniche Life Sciences Inc. Belleville ON, Canada.

\section{References}

Agarwal, V.K., Thappa, R.K., Agarwal, S.G., Dhar, K.L., 1984. Phenolic constituents of Iris milesii rhizomes. Phytochemistry 23, 1342-1343.

Amiguet, V.T., Arnason, J.T., Maquin, P., Cal, V., Vindas, P.S., Poveda, L., 2005. A consensus ethnobotany of the Q'eqchi' Maya of Southern Belize. Econ. Bot. 59, 29-42.

Awad, R., Arnason, J.T., Trudeau, V., Bergeron, C., Budzinski, J.W., Foster, B.C., Merali, Z., 2003. Phytochemical and biological analysis of Skullcap (Scutellaria lateriflora L.): A medicinal plant with anxiolytic properties. Phytomedicine 10, 640-649.

Awad, R., Ahmed, F., Bourbonnais-Spear, N., Mullally, M., Ta, C.A., Tang, A., Merali, Z., Maquin, P., Caal, F., Cal, V., Poveda, L., Vindas, P.S., Trudeau, V.L., Arnason, J.T., 2009. Ethnopharmacology of Q'eqchi' Maya antiepileptic and anxiolytic plants: effects on the GABAergic system. J. Ethnopharmacol. 125, 257-264.

Bourbonnais-Spear, N., Awad, R., Merali, Z., Maquin, P., Cal, V., Arnason, J.T., 2007. Ethnopharmacological investigation of plants used to treat susto, a folk illness. J. Ethnopharmacol. 109, 380-387.

Das, M.C., Shashi, B.M., 1982. Triterpenoid sapogenols from the leaves of Careya arborea: structure of careyagenolide. Phytochemistry 21, 2069-2073.

Doddrell, D.M., Khong, P.W., Lewis, K.G., 1974. Stereochemical dependence of carbon-13 chemical shifts in olean-12-enes and urs-12-enes as an aid to structural assignment. Tetrahedron Lett. 27, 2381-2384.

Duddeck, H., Snatzke, G., Yemul, S.S., 1978. ${ }^{13} \mathrm{C}$ NMR and CD of some 3,8biflavanoids from Garcinia species and of related flavanones. Phytochemistry 17, 1369-1373.

Fujioka, T., Kashiwada, Y., Kikuskie, R.E., Cosentino, L.M., Ballas, L.M., Jiang, J.B., Janzen, W.P., Chen, I.S., Lee, K.H., 1994. J. Nat. Prod. 57, 243-247.

Gentry, A.H., 1993. A Field Guide to the Families and Genera of Woody Plants of Northwest South America (Colombia, Ecuador, Peru) with Supplementary Notes on Herbaceous Taxa. The University of Chicago Press, Chicago and London.
Iyer, C.S.R., Iyer, P.R., 1978. Steroids from Grangea maderaspatana. Phytochemistry $17,2036-2037$

Junkuszew, M., Oleszek, W., Jurzysta, M., Piancente, S., Pizza, C., 1998. Triterpenoid saponins from the seeds of Amaranthus cruentus. Phytochemistry 49, 195-198.

Kojima, H., Ogura, H., 1986. Triterpenoids from Prunella vulgaris. Phytochemistry 25 729-733.

Kokpol, U., Chavasiri, W., Chittawong, V., Miles, D.H., 1990. Taraxeryl cis-phydroxycinnamate, a novel taraxeryl from Rhizophora apiculata. J. Nat. Prod. 53, 953-955.

Lam, J., Wrang, P., 1975. Flavonoids and polyacetylenes in Dahlia tenuicaulis. Phytochemistry 14, 1621-1623.

Mahato, S.B., Kundu, A.P., $1994 .{ }^{13} \mathrm{C}$ NMR spectra of pentacyclic triterpenoids - a compilation and some salient features. Phytochemistry 37, 1517-1575.

Miyazawa, M., Okuno, Y., Nakamura, S., Kosaka, H., 2000. Antimutagenic activity of flavonoids from Pogostemon cablin. J. Agric. Food Chem. 48, 642-647.

Muceniece, R., Saleniece, K., Rumaks, J., Krigere, L., Dzirkale, Z., Mezhapuke, R. Zharkova, O., Klusa, V., 2008. Betulin binds to GABA receptors and exerts anticonvulsant action in mice. Pharmacol. Biochem. Behav. 90, 712-716.

Mullally, M., Kramp, K., Cayer, C., Saleem, A., Ahmed, F., McRae, C., Baker, J., Goulah, A., Otarola, M., Sanchez, P., Garcia, M., Poveda, L., Merali, Z., Durst, T., Trudea, V.L., Arnason, J.T., 2011. Anxiolytic activity of a supercritical carbon dioxide extract of Souroubea sympetala. Phytother. Res. 25, 264-270.

Rauter, A.P., Branco, I., Tosrão, Z., Pais, M.S., Gonzalez, A.G., Bermejo, J.B., 1989 Flavonoids from Artemisia campestris subsp. marítima. Phytochemistry 28, 2173-2175.

Rossi, M.H., Yoshida, M., Maia, J.G.S., 1997. Neolignans, styrylpyrones and flavonoids from an Aniba species. Phytochemistry 45, 1263-1269.

Sakurai, N., Yaguchi, Y., Inoue, T., 1986. Triterpenoids from Myrica rubra. Phytochemistry 26, 217-219.

Schultes, R.E., Raffauf, R.F., 1990. The Healing Forest: Medicinal and Toxic Plants of the Northwest Amazonia. Dioscorides Press, Portland.

Seo, S., Tomita, Y., Tori, K., 1981. Biosynthesis of oleanene- and ursene-type triterpenes from [4-13C]mevalonolactone and [1,2-13C2]acetate in tissue cultures of Isodon japonicus Hara. J. Am. Chem. Soc. 103, 2075-2080.

Seo, S., Tomita, Y., Tori, K., 1975. Carbon-13 nmr spectra of urs-12-enes and application to structural assignments of components of Isodon japonicus hara tissue cultures. Tetrahedron Lett. 16, 7-10.

Sucrow, W., Slopianka, M., Kircher, H.W., 1976. The occurrence of $C_{29}$ sterols with different configurations at C-24 in Cucurbita pepo as shown by $270 \mathrm{MHz}$ NMR. Phytochemistry 15, 1533-1535.

Talapatra, B., Basak, A., Talapatra, S.K., 1981. Terpenoids and related compounds. Part XX. Careaborin, a new triterpene ester from the leaves of Careya arborea. J. Ind. Chem. Soc. 58, 814-815.

Vasconcelos, J.M.J., Silva, A.M.S., Cavaleiro, J.A.S., 1998. Chromones and flavanones from Artemisia campestris subsp. Maritima. Phytochemistry 49, 1421-1424.

Vasques da Silva, R., Debonsi Navickiene, H.M., Kato, M.J., Da Bolzani, V.S., Méda, C.I., Young, M.C.M., Furlan, M., 2002. Microbial transformation of cadina-4,10(15)dien-3-one, aromadendr-1(10)-en-9-one and methyl ursolate by Mucor plumbeus ATCC 4740. Phytochemistry 59, 479-488.

Yogeeswari, P., Sriram, D., 2005. Betulinic acid and its derivatives: a review on their biological properties. Curr. Med. Chem. 12, 657-666. 